\title{
Growth and Yield of Castor Hybrids at Varying Nitrogen Levels in Andhra Pradesh, India
}

\author{
B. Bhargavi*, M. Sree Rekha, P.V.N. Prasad and K. Jayalalitha
}

Department of Agronomy, Agricultural College (ANGRAU), Bapatla, Andhra Pradesh, India

*Corresponding author

\section{A B S T R A C T}

\section{Key words \\ Castor, Hybrids, Nitrogen, SPAD Chlorophyll meter \\ Article Info \\ Accepted: 17 July 2018 Available Online: 10 August 2018}

The present study was conducted to evaluate the response of three castor hybrids (PCH 111, GCH 4, Western Maruthi) to varying nitrogen levels (60, 80, 100 and 120 $\mathrm{kg} \mathrm{N} \mathrm{ha}{ }^{-1}$ ) under rainfed conditions at Agricultural College Farm, Bapatla during kharif, 2017. The growth characters viz., plant height and dry matter accumulation at harvest, days to maturity and SPAD chlorophyll meter reading as well as yield attributing parameters viz., number of capsules per primary spike and test weight as well as bean yield were significantly higher with PCH 111 hybrid and it was closely followed by hybrid GCH 4. Application of $120 \mathrm{~kg} \mathrm{~N} \mathrm{ha}^{-1}$ recorded the highest growth and vield parameters.

\section{Introduction}

Castor is one of the important non-edible oil seed cash crop grown widely in rainfed areas of India. The productivity of this crop in rainfed environment quite often fluctuates due to vagaries of monsoon. The low productivity of rainfed castor is attributed to its cultivation under marginal soils having low available nitrogen. It is also attributed to the erratic rainfall distribution, use of non-descriptive cultivars and poor management practices.

Castor is exhaustive crop and responds well to the added fertilizers. Keeping these facts in view an experiment was conducted to study growth and yield of on different hybrids response to nitrogen doses.

\section{Materials and Methods}

A field trial was carried out during kharif 2017 on clay soil at Agricultural College Farm, Bapatla. It is situated at an altitude of $5.49 \mathrm{~m}$ above mean sea level, $15^{\circ} 54^{\prime} \mathrm{N}$ latitude, $80^{\circ}$ $25^{\prime} \mathrm{E}$ longitude. The soil was clayey in texture, slightly alkaline in reaction, low in organic carbon $(0.3 \%)$, low in available nitrogen (200 $\left.\mathrm{kg} \mathrm{ha}^{-1}\right)$, high in available phosphorus $(28.7 \mathrm{~kg}$ $\mathrm{ha}^{-1}$ ) and available potassium (307 $\mathrm{kg} \mathrm{ha}^{-1}$ ). The mean maximum and minimum temperatures during crop growth period ranged from $37.6{ }^{\circ} \mathrm{C}$ and $26.1^{\circ} \mathrm{C}$ respectively. A total of $686.6 \mathrm{~mm}$ rainfall was received during crop growth period in 28 rainy days. The experiment was replicated thrice where in twelve treatment combinations comprising of 
three hybrids and four levels of nitrogen were tested in randomized block design with factorial concept. The crop was sown on $3^{\text {rd }}$ August, 2017. Nitrogen was applied in the form of urea $(46 \% \mathrm{~N})$ as per the treatments in 3 splits i.e., $1 / 2$ at the time of sowing, $1 / 4$ at 30 35 DAS and $1 / 4$ at 60-65 DAS. A common dose of $40 \mathrm{~kg} \mathrm{P}_{2} \mathrm{O}_{5}$ and $30 \mathrm{~kg} \mathrm{~K}_{2} \mathrm{O}$ ha $^{-1}$ was applied in the form of single superphosphate $\left(16 \% \mathrm{P}_{2} \mathrm{O}_{5}\right)$ and muriate of potash $\left(60 \% \mathrm{~K}_{2} \mathrm{O}\right)$, respectively, as basal. Standard procedures were adopted for recording data on various growth and yield parameters. Necessary plant protection measures were taken. The data were analyzed statistically by adopting the standard procedure described by Gomez and Gomez (1984).

\section{Results and Discussion}

\section{Growth parameters}

The data on growth parameters of different castor hybrids as influenced by nitrogen levels are presented in Table 1. There was no significant variation in plant height recorded at 30 DAS in different hybrids. Castor hybrid GCH 4 recorded maximum plant height (67.2 $\mathrm{cm})$ at 60 DAS which was significantly superior to the other two hybrids tested viz.., PCH 111 and Western Maruthi.

At 90 DAS and at harvest significantly taller plants were obtained with PCH 111 compared to $\mathrm{GCH}$ 4. The differences in plant height observed among the castor hybrids might be due to their differences in genetic makeup. Significantly higher plant height of $121.4 \mathrm{~cm}$ was noticed with $120 \mathrm{~kg} \mathrm{~N} \mathrm{ha}^{-1}$ than lower nutrient levels and the lowest was recorded with application of $60 \mathrm{kgNha}^{-1}$.

This, increasing trend in plant height might be due to the reason that nitrogen hastens the metabolic activity in the plant body by synthesizing tryptophan, a precursor for the auxins, which in turn resulted in increased plant height. But under limited availability of nitrogen reduced cell divison and elongation occurs which ultimately reduced the plant height. The results obtained in present study are in close agreement with Torres et al., (2016) and Hanumanthappa et al., (2011).

Drymatter accumulation is one of the important parameter which influences the crop growth. Drymattter accumulation with $\mathrm{GCH} 4$ at 60 DAS was highest with $694 \mathrm{~kg} \mathrm{ha}^{-1}$ which was significantly superior to Western Maruthi $\left(581 \mathrm{~kg} \mathrm{ha}^{-1}\right)$. At 90 DAS and harvest, the drymatter accumulation with PCH 111 with (4234, $6663 \mathrm{~kg} \mathrm{ha}^{-1}$ ) was significantly higher when compared with $\mathrm{GCH} 4(3018,5419 \mathrm{~kg}$ $\mathrm{ha}^{-1}$ ) and Western Maruthi (3558, $5892 \mathrm{~kg}$ $\mathrm{ha}^{-1}$ ), respectively. The increase in drymatter accumulation with $\mathrm{PCH} 111$ was 40.2 per cent and 22.9 per cent, over GCH 4 while it was 18.9 per cent and 13.0 per cent, higher with Western Maruthi at 90 DAS and at harvest, respectively. Nitrogen levels had a significant influence on drymatter accumulation from 60 DAS to maturity.

Application of nitrogen @ 120 kg N ha ${ }^{-1}$ resulted in maximum accumulation of drymatter which was significantly superior to $60 \mathrm{~kg} \mathrm{~N} \mathrm{ha}{ }^{-1}$ and on a par with $80 \mathrm{~kg} \mathrm{~N} \mathrm{ha}^{-1}$ and $100 \mathrm{~kg} \mathrm{~N} \mathrm{ha}^{-1}$ at 60 DAS. At 90 DAS and at harvest, $120 \mathrm{~kg} \mathrm{~N} \mathrm{ha}{ }^{-1}$ recorded significantly highest drymatter over $60 \mathrm{~kg} \mathrm{~N}$ $\mathrm{ha}^{-1}$ and $80 \mathrm{~kg} \mathrm{~N} \mathrm{ha}^{-1}$ levels. At $90 \mathrm{DAS}$, the drymatter accumulation was significantly influenced by the interaction between hybrids and nitrogen levels. The highest drymatter accumulation (4596 kg ha $\mathrm{kg}^{-1}$ was with combination of PCH 111 and $120 \mathrm{~kg} \mathrm{~N}^{-1}$ which was on a par with PCH 111 and $100 \mathrm{~kg}$ $\mathrm{N} \mathrm{ha}^{-1}$ and Western Maruthi and $120 \mathrm{~kg} \mathrm{~N}^{-1}$ where the drymatter production was $4203 \mathrm{~kg}$ $\mathrm{ha}^{-1}$ and $4370 \mathrm{~kg} \mathrm{ha}{ }^{-1}$ respectively and were significantly superior to all other treatment combinations (Table 2). 
Table.1 Growth parameters of castor as influenced by hybrids and nitrogen levels

\begin{tabular}{|c|c|c|c|c|c|c|c|c|c|c|}
\hline \multirow[t]{2}{*}{ Treatment } & \multicolumn{4}{|c|}{ Plant height (cm) } & \multicolumn{4}{|c|}{ Drymatter accumulation } & \multirow{2}{*}{$\begin{array}{l}\text { (Days to } \\
\text { maturity) }\end{array}$} & \multirow{2}{*}{$\begin{array}{l}\text { SPAD chlorophyll } \\
\text { meter }\end{array}$} \\
\hline & 30 & 60 & 90 & $\begin{array}{c}\text { At } \\
\text { harvest }\end{array}$ & 30 & 60 & 90 & $\begin{array}{c}\text { At } \\
\text { harvest }\end{array}$ & & \\
\hline \multicolumn{11}{|l|}{ Hybrids } \\
\hline $\mathrm{V}_{1}-\mathrm{PCH} 111$ & 28.3 & 59.4 & 110.6 & 111.3 & 57 & 607 & 4234 & 6663 & 158 & 44.9 \\
\hline $\mathrm{V}_{2}-\mathrm{GCH} 4$ & 30.2 & 67.2 & 96.4 & 95.9 & 58 & 694 & 3018 & 5419 & 145 & 46.7 \\
\hline V 3 - Western Maruthi & 28.2 & 60.4 & 109.3 & 110.8 & 56 & 581 & 3558 & 5892 & 170 & 46.1 \\
\hline S.Em \pm & 0.72 & 1.99 & 3.10 & 2.43 & 2.5 & 29.8 & 115.9 & 141.4 & 0.54 & 0.61 \\
\hline CD $(p=0.05)$ & NS & 5.8 & 9.0 & 7.1 & NS & 87.5 & 340.1 & 417.4 & 1.5 & NS \\
\hline \multicolumn{11}{|l|}{ Nitrogen levels $\left(\mathrm{kg} \mathrm{ha}^{-1}\right)$} \\
\hline$N_{1}-60$ & 28.4 & 57.0 & 92.4 & 93.1 & 54 & 545 & 3202 & 5543 & 157 & 43.3 \\
\hline $\mathbf{N}_{2}-80$ & 29.0 & 61.9 & 93.3 & 93.9 & 57 & 608 & 3536 & 5808 & 157 & 45.1 \\
\hline $\mathbf{N}_{3}-100$ & 28.9 & 63.6 & 115.9 & 115.7 & 58 & 659 & 3711 & 6105 & 158 & 47.0 \\
\hline$N_{4}-120$ & 29.2 & 66.8 & 120.1 & 121.4 & 59 & 699 & 3965 & 6508 & 160 & 48.2 \\
\hline S.Em & 0.83 & 2.30 & 3.58 & 2.81 & 2.9 & 34.4 & 133.9 & 163.2 & 0.62 & 0.70 \\
\hline$C D(p=0.05)$ & NS & 6.7 & 10.5 & 8.26 & NS & 101.0 & 392.7 & 478.8 & 1.8 & 2.0 \\
\hline \multicolumn{11}{|l|}{ Interaction (VX N) } \\
\hline S.Em & 1.44 & 3.99 & 6.20 & 4.87 & 5.0 & 59.70 & 231.9 & 282.8 & NS & 1.2 \\
\hline$C D(p=0.05)$ & NS & NS & NS & NS & NS & NS & 680.2 & NS & 1.1 & NS \\
\hline $\mathrm{CV}(\%)$ & 8.61 & 11.0 & 10.1 & 7.9 & 15.1 & 16.4 & 11.1 & 8.1 & & 4.6 \\
\hline
\end{tabular}


Table.2 Interaction between castor hybrids and nitrogen on drymatter production at 90 DAS $\left(\mathrm{kg} \mathrm{ha}^{-1}\right)$

\begin{tabular}{|c|} 
Hybrids \\
\hline $\mathrm{V}_{1}-\mathrm{PCH} 111$ \\
\hline $\mathrm{V}_{2}-\mathrm{GCH} 4$ \\
\hline $\mathbf{V}_{3}-$ Wesern Maruthi \\
\hline Mean \\
\hline S.Em \pm \\
\hline $\mathrm{CD}(\mathrm{p}=0.05)$ \\
\hline
\end{tabular}

\begin{tabular}{|c|c|c|c|c|}
\hline \multicolumn{4}{|c|}{$\mathbf{N}$ levels $\left(\mathrm{kg} \mathrm{ha}^{-1}\right)$} & \multirow[t]{2}{*}{ Mean } \\
\hline$N_{1}-60$ & $N_{2}-80$ & $\mathbf{N}_{3}-\mathbf{1 0 0}$ & $N_{4}-120$ & \\
\hline 4083 & 4060 & 4203 & 4596 & 4234 \\
\hline 2632 & 3500 & 3005 & 2937 & 3018 \\
\hline 2890 & 3049 & 3925 & 4370 & 3558 \\
\hline 3202 & 3536 & 3711 & 3965 & \\
\hline \multicolumn{5}{|c|}{231.9} \\
\hline \multicolumn{5}{|c|}{680.2} \\
\hline
\end{tabular}

Table.3 Yield attributes and bean yield of castor as influenced by hybrids and nitrogen levels

\begin{tabular}{|c|}
\hline Treatment \\
\hline Hybrids \\
\hline $\mathrm{V}_{1}-\mathrm{PCH} 111$ \\
\hline $\mathrm{V}_{2}-\mathrm{GCH} 4$ \\
\hline $\mathbf{V}_{3}-$ Western Maruthi \\
\hline S.Em \pm \\
\hline$C D(p=0.05)$ \\
\hline Nitrogen levels \\
\hline$N_{1}-60$ \\
\hline $\mathbf{N}_{2}-80$ \\
\hline $\mathbf{N}_{3}-100$ \\
\hline$N_{4}-120$ \\
\hline S.Em \\
\hline $\mathrm{CD}(\mathrm{p}=0.05)$ \\
\hline Interaction (V X N) \\
\hline S.Em \pm \\
\hline$C D(p=0.05)$ \\
\hline $\mathrm{CV}(\%)$ \\
\hline
\end{tabular}

\begin{tabular}{|l|l|l|}
\hline \multicolumn{1}{|c|}{$\begin{array}{c}\text { No. of capsules } \\
\text { primary spike }\end{array}$} & $\begin{array}{c}\text { Test weight } \\
(\mathrm{g} / \text { 100 beans) }\end{array}$ & \multicolumn{1}{c|}{ Bean yield $\left(\mathrm{kg} \mathrm{ha}^{-1}\right)$} \\
\hline 90 & 26.5 & 2703 \\
\hline 72 & 26.4 & 2494 \\
\hline 67 & 26.7 & 1899 \\
\hline 1.99 & 0.24 & 84.9 \\
\hline 5.8 & $\mathrm{NS}$ & 249.2 \\
\hline 67 & & \\
\hline 71 & 26.1 & 2015 \\
\hline 79 & 26.2 & 2159 \\
\hline 88 & 26.9 & 2505 \\
\hline 2.30 & 27.0 & 2781 \\
\hline 6.7 & 0.28 & 98.1 \\
\hline & $\mathrm{NS}$ & 287.8 \\
\hline 3.99 & & \\
\hline NS & 0.48 & 169.9 \\
\hline 9.0 & $\mathrm{NS}$ & 498.5 \\
\hline
\end{tabular}

Table.4 Interaction between hybrids and nitrogen in castor $\left(\mathrm{kg} \mathrm{ha}^{-1}\right)$

\begin{tabular}{l} 
Hybrids \\
\hline $\mathrm{V}_{1}-\mathrm{PCH} 111$ \\
\hline $\mathrm{V}_{2}-$ GCH 4 \\
\hline $\mathrm{V}_{3}-$ Western Maruthi \\
\hline Mean \\
\hline S.Em \pm \\
\hline CD $(\mathrm{p}=0.05)$ \\
\hline
\end{tabular}

\begin{tabular}{|c|c|c|c|c|}
\hline \multicolumn{4}{|c|}{$\mathbf{N}$ levels $\left(\mathrm{kg} \mathrm{ha}^{-1}\right)$} & \multirow[t]{2}{*}{ Mean } \\
\hline$N_{1}-60$ & $\mathrm{~N}_{2}-\mathbf{8 0}$ & $\mathbf{N}_{3}-100$ & $N_{4}-120$ & \\
\hline 2035 & 2140 & 3242 & 3396 & 2703 \\
\hline 2156 & 2406 & 2498 & 2914 & 2494 \\
\hline 1854 & 1932 & 1775 & 2034 & 1899 \\
\hline 2015 & 2159 & 2505 & 2781 & \\
\hline \multicolumn{5}{|c|}{169.9} \\
\hline \multicolumn{5}{|c|}{498.5} \\
\hline
\end{tabular}


The probable reason for such a positive response upto $120 \mathrm{~kg} \mathrm{~N} \mathrm{ha}^{-1}$ was availability of nitrogen in synchrony with crop need which has resulted in good vegetative growth, better root development and efficient photosynthesis and finally accumulated more drymatter. Such increase in drymatter with the application of nitrogen was also reported by Sarada Devi et al., (2002) and Lakshmi and Sambasiva Reddy (2006).

Castor hybrid, Western Maruthi took maximum number of days (170) to attain maturity and it was significantly superior to the other two hybrids. Earliness in GCH 4 hybrid is due to early set of reproductive activity. The delay to reach maturity in $\mathrm{PCH} 111$ and Western Maruthi might be due to highest plant height, more number of branches which resulted in luxurious growth of the crop and took more number of days before the crop transformed from vegetative to reproductive phase, leading to delay in harvest. Application of maximum dose of nitrogen $120 \mathrm{~kg} \mathrm{~N}$ ha $^{-1}$ took highest number of days to mature and was significantly superior to other doses of nitrogen applied. The present results corroborate with the findings of Venugopal et al., (2006) and Mishra and Tewari (2014). The hybrids of castor could not reach the level of significance for SPAD chlorophyll meter reading. Nitrogen @ 120 kg N ha ${ }^{-1}$ resulted in maximum chlorophyll content which was significantly superior to that of $60 \mathrm{~kg} \mathrm{~N} \mathrm{ha}^{-1}$ and $80 \mathrm{~kg} \mathrm{~N} \mathrm{ha}^{-1}$ and was on a par with that of $100 \mathrm{~kg} \mathrm{~N} \mathrm{ha}^{-1}$. Increase in nitrogen dose might have contributed to chlorophyll content of castor with incremental doses of nitrogen.

\section{Yield attributes and yield}

There was a significant difference in the yield components viz., number of capsules per spike and test weight (Table 3). Castor hybrid, PCH 111 recorded significantly higher number of capsules per primary spike (90) whereas Western Maruthi recorded significantly lowest number of capsules per primary spike (67). More plant height, higher drymatter accumulation and a better source-sink relationship established in $\mathrm{PCH} 111$ hybrid might have resulted in greater number of capsules primary spike ${ }^{-1}$ than Western Maruthi which might be due to inefficient drymatter partitioning. Among levels of nitrogen, maximum number of capsules per primary spike were recorded when $120 \mathrm{~kg} \mathrm{~N} \mathrm{ha}^{-1}$ was applied and it was significantly superior to other rates of nitrogen application. Similarly, $100 \mathrm{~kg} \mathrm{~N}^{-1}$ recorded 79 capsules per primary spike which was significantly superior to that of $80 \mathrm{~kg} \mathrm{~N} \mathrm{ha}^{-1}$ and $60 \mathrm{~kg} \mathrm{~N} \mathrm{ha}{ }^{-1}$. The increase in number of capsules primary spike ${ }^{-1}$ was in the order of $31.9,23.9,11.3$ per cent, with 120,80 and 100 $\mathrm{kg} \mathrm{N} \mathrm{ha}{ }^{-1}$, respectively over $60 \mathrm{~kg} \mathrm{~N} \mathrm{ha}^{-1}$. This shows that increased availability of nitrogen in sufficient quantities increased the drymatter accumulation of plants, which might have acted as a source to supply nutrients to reproductive parts i.e. flowers and capsules which might have increased the number of capsules primary spike $^{-1}$. The data on test weight recorded indicated that hybrids and nitrogen levels could not reach the level of significance However, numerically increase in nitrogen levels from 60 - $120 \mathrm{~kg} \mathrm{~N} \mathrm{ha}^{-1}$ improved the test weight $(\mathrm{g})$ in increasing trend. These findings are in consonance with those of and Vijay Bhaskar Reddy et al., (2007) and Hanumantahappa et al., (2011).

Castor hybrid PCH 111 recorded maximum bean yield of $2703 \mathrm{~kg} \mathrm{ha}$ which was significantly superior to Western Maruthi with $1899 \mathrm{~kg} \mathrm{ha}^{-1}$. There was 42.3 per cent increase in bean yield with PCH 111 over Western Maruthi. In PCH 111 and GCH 4 more number of total spikes plant ${ }^{-1}$ and capsules spike ${ }^{-1}$ have contributed the maximum bean yield when compared with other hybrid. These are physiologically important yield attributes, which have a positive correlation with bean yield of castor and also due to delayed senescence of leaves which helped these hybrids to produce more photosynthates, thus increasing the assimilatory efficiency. The lowest seed yield recorded in Western Maruthi might be due to poor source- sink relationship and lower yield attributes. Application of 120 
$\mathrm{kg} \mathrm{N}$ ha $^{-1}$ significantly enhanced the bean yield $\left(2781 \mathrm{~kg} \mathrm{ha}^{-1}\right)$ over rest of the nitrogen levels but it remained on par with $100 \mathrm{~kg} \mathrm{~N} \mathrm{ha}^{-1}$ and it was 38.0 per cent higher than that of $60 \mathrm{~kg} \mathrm{~N}$ $\mathrm{ha}^{-1}$. The interaction effect between hybrids and nitrogen levels on total castor bean yield presented in Table 4 showed that maximum bean yield $3396 \mathrm{~kg} \mathrm{ha}^{-1}$ was attained with the treatment $\mathrm{PCH} 111$ at $120 \mathrm{~kg} \mathrm{~N} \mathrm{ha}^{-1}$. However, it was statistically on par with PCH 111 at 100 $\mathrm{kg} \mathrm{N}^{-1}$ with $3342 \mathrm{~kg} \mathrm{ha}^{-1}$ and GCH 4 at 120 $\mathrm{kg} \mathrm{N}$ ha $^{-1}$ with $2914 \mathrm{~kg} \mathrm{ha}^{-1}$.

The increase in bean yield of castor due to more synchronous availability of ' $\mathrm{N}$ ' as per crop need with the application of $120 \mathrm{~kg} \mathrm{~N} \mathrm{ha}^{-1}$ might have tended to put more vegetative growth, better root development, more drymatter accumulation and yield attributing characters which resulted in efficient photosynthesis and finally produced more bean yield. The present results are in conformity with those of Torres et al., (2016) and Man et al., (2017). Based on this study, it can be concluded that cultivation of castor variety PCH 111 and GCH 4 with $120 \mathrm{~kg}$ $\mathrm{N} \mathrm{ha}^{-1}$ has recorded higher growth and yield parameters and bean yield in Andhra Pradesh under rainfed condition.

\section{References}

Gomez, A.K., and Gomez, A. A. 198 Statistical procedures for Agricultural Research. John Wiley and Sons, Singapore.

Hanumanthappa, D.C., Mudalagiriyappa, Krishnappa, M., Prakash, J.C and Shashikumar, C. 2011 Performance of castor (Ricinus communis L.) genotypes at different nutrient levels under rainfed in central dry zone of Karnataka. Mysore Journal of Agricultural Research. 45(3): 516-520.
Lakshmi, Y. S and Sambasiva Reddy, A. 2006 Effect of plant densities on growth and yield of castor varieties. Crop Research. 32 (1): 32-35.

Man, M.K., Amin, A.U., Choudhary, K.M and Gora, A.D. 2017. Response of castor (Ricinus communis L.) to varying weather variables and crop geometry with levels of nitrogen under rabi Season. International Journal of Current Microbiological Applied Sciences. 6(5): 2409-2418

Mishra, A and Tewari, N. 2014 Effect of date of sowing on yield and yield components of castor (Ricinus communis L.) cultivars under irrigated condition in Central Region of Uttar Pradesh. International Journal of Modern Plant and Animal Sciences. 2(1): 26-32.

Sarada Devi, Y, Subrahmanyam, M. V. R. and Bheemaiah, G. 2002. Effect of cropping systems and nitrogen levels on growth, yield and economics of rainfed castor intercropped with Melia azadirachta Linn. Journal of Oilseeds Research. 19 (1): 154-156.

Torres, F. E, Teodoro, P. E, Hernandes, F.B, Fernandes, R.1 and Gomes, A. C 2016. Agronomic performance of castor under different growing conditions. Bioscience Journal. 32 (1): 55-60.

Venugopal, C., Reddy, G.K., Reddy, D.S. 2006. Seed yield and net returns of rainfed castor (Ricinus commumis L.) as influenced by plant geometry and nitrogen levels. Journal of Oilseed Research. 23 (2): 356-357.

Vijaya Bhaskar Reddy, U., Prabhakara Reddy, G and Srinivasulu Reddy, D. 2007. Yield and oil content of castor varieties as influenced by planting dates. Indian Journal of Dryland Agricultural Research \& Development. 22 (1): 114-116.

\section{How to cite this article:}

Bhargavi, B., M. Sree Rekha, P.V.N. Prasad and Jayalalitha, K. 2018. Growth and Yield of Castor Hybrids at Varying Nitrogen Levels in Andhra Pradesh, India. Int.J.Curr.Microbiol.App.Sci. 7(08): 3178-3183. doi: https://doi.org/10.20546/ijcmas.2018.708.340 